\title{
AN ANNOTATED CHECKLIST OF THE CLADOCERA OF CUBA
}

\author{
BY \\ MANUEL ELÍAS-GUTIÉRREZ ${ }^{1,3}$ ) and CARLOS VARELA ${ }^{2,4}$ ) \\ 1) El Colegio de la Frontera Sur, Av. Centenario Km 5.5, Chetumal 77014, Quintana Roo, Mexico \\ ${ }^{2}$ ) Departamento de Acuariología, Acuario Nacional de Cuba, Calle 1ra \#6002 e/e 60 y 62, \\ C. P. 11300, Playa, Ciudad de La Habana, Cuba
}

\begin{abstract}
Although Cuba is the most studied Caribbean island with regard to freshwater Cladocera, our knowledge of their species composition and distribution is still limited. In this study, all available published and unpublished, reliable sources were reviewed for all records of this group of crustaceans. Thus, a revised and updated list of 70 species of the orders Ctenopoda and Anomopoda recorded for the island is here presented, including all sources of information. From the total number of records, about $32 \%$ are doubtful. Comments on these and on other selected species are included. From a biogeographical point of view, the fauna of Cuba is closely related to that of southern Mexico, and both regions have a close similarity with South America. The actual distribution of the species can be explained on the basis of the origin of the Proto-Antilles-Central America complex, of which the island of Cuba is the most diverse representative among the Recent Caribbean islands.
\end{abstract}

\section{RESUMEN}

Aunque Cuba es la isla caribeña mejor estudiada para los cladóceros de agua dulce, el conocimiento de su composición y distribución es aún limitado. En este trabajo se revisaron todas las fuentes con registros de datos fidedignos publicados y no publicados para este grupo de crustáceos. En este trabajo se presenta una lista revisada y actualizada de 70 especies de los órdenes Ctenopoda y Anomopoda registrados en esta isla, incluyendo las fuentes de información. Del total de registros, aproximadamente el $32 \%$ son dudosos. Se incluyen comentarios sobre éstas y otras especies seleccionadas. Desde el punto de vista biogeográfico, la fauna de Cuba se encuentra estrechamente relacionada con el sur de México, y ambas regiones tienen una estrecha similitud con Sudamérica. La distribución actual de estas especies puede ser explicada en base del origen del complejo representado por las Proto-Antillas-Centroamérica. Como resultado Cuba es la isla con mayor diversidad del Caribe.

3) e-mail: melias@ecosur.mx

4) e-mail: varela06@gmail.com 


\section{INTRODUCTION}

Cuba, the largest Caribbean island with a freshwater fauna, seems to be relatively well known. Among the tropical countries, it was extensively studied, mainly by foreign researchers, since the first half of the 20th century. The first mention of cladocerans from its inland waters was by Brehm (1948), who described a new moinid and gave a list of seven species. Straškraba et al. (1969) and Straškraba (1969) listed several species from various reservoirs and discussed their biogeographic affinities. Then, due to the activity of the Cuban-Romanian Biospeleological Expedition, the epigean and hypogean species of cladocerans were recorded in two papers by Orghidan \& Negrea (1970, 1973). Biochino (1976) published a list of the Cladocera associated with aquatic plants in various reservoirs. In 1964-1966, the joint Czechoslovakian-Cuban Expedition collected material from many localities of Cuba. Data generated from this expedition were published subsequently by other researchers, as Collado et al. (1984), who presented a list of species recorded at that time. In the same year, Alonso (1984) gave a detailed list of all zooplankters dwelling in the Laguna El Tesoro. Before these two publications, Frey (1982) presented a list including species from previous studies and unpublished records by V. Kořínek and C. H. Fernando. During subsequent years, sporadic studies increased the number of species and new compilations were made (Lalana et al., 2005). Recently, taxonomic changes after careful analyses of many species, discovery of new ones, as well as the dramatic reduction of "true" cosmopolitans, make it necessary to update the list of Cladocera known from this island.

\section{METHODS}

To produce this list, an extensive review of published and unpublished, reliable sources was carried out for all records of Cladocera. Each record was updated to the actual valid names. All cases of published names, considered as doubtful to be found in the island of Cuba, were noted and are marked as such in the present paper.

\section{RESULTS AND DISCUSSION}

In total, 70 species of Cladocera have been recorded from Cuba to date, but 23 of these records are doubtful (table I). Comments on selected species as well as some biogeographical remarks are provided in the next section.

Sididae. - Since Kořínek (1981) described Diaphanosoma birgei, a congener of D. brachyurum (Liévin, 1848) from the Old World, it has been accepted that all 


\section{TABLE I}

Species of Cladocera from Cuba. Sources: 1, Brehm (1948); 2, Straškraba (1969); 3, Orghidan \& Negrea (1970); 4, Orghidan \& Negrea (1973); 5, Biochino (1976); 6, Frey (1982); 7, Collado et al. (1984); 8, Kořínek (1981); 9, Alonso (1984); 10, Kořínek (1984); 11, Korovchinsky (1992); 12, Kotov et al. (2005); 13, V. Kořínek (in litt.); 14, Lalana et al. (2005). ^, Species probably found in Cuba (see text); *, doubtful records; ${ }^{\wedge}$, includes L. occidentalis and L. fasciculata; ${ }^{\mathrm{x}}$, cited as Alona macrocantha; ${ }^{\bullet}$, marine species; ${ }^{\star}$, subgenus sensu Kotov (2009). All names are given according to the actual nomenclature, and because of this reason some names from the original lists have changed (see text)

\begin{tabular}{|c|c|}
\hline Taxon & Source \\
\hline \multicolumn{2}{|l|}{ SIDIDAE Baird, 1850} \\
\hline 1. ${ }^{\wedge}$ Latonopsis australis G. O. Sars, 1888 group & 6,13 \\
\hline 2. *Diaphanosoma brachyurum (Liévin, 1848) & $3,4,6,7,9$ \\
\hline 3. D. brevireme G. O. Sars, 1901 & $6,7,14$ \\
\hline 4. D. spinulosum Herbst, 1967 & $6,7,14$ \\
\hline 5. D. birgei Kořínek, 1981 & $6,8,13,14$ \\
\hline 6. Sarsilatona serricauda (G. O. Sars, 1901) & 13 \\
\hline 7. Pseudosida bidentata Herrick, 1884 & 5,6 \\
\hline 8. P. ramosa (Daday, 1904) & $6,13,11$ \\
\hline \multicolumn{2}{|l|}{ DAPHNIIDAE Straus, 1820} \\
\hline 9. Daphnia laevis Birge, 1878 & $6,7,14$ \\
\hline 10. D. pulicaria Forbes, 1893 & 6,7 \\
\hline 11. D. parvula Fordyce, 1901 & 6,7 \\
\hline 12. D. ambigua Scourfield, 1947 & $2,6,9$ \\
\hline 13. * Ceriodaphnia cf. quadrangula (O. F. Müller, 1785) & 9 \\
\hline 14. ${ }^{*}$ C. cornuta G. O. Sars, 1886 & $4,6,7$ \\
\hline $15 .{ }^{*}$ C. rigaudi Richard, 1894 & 4,6 \\
\hline 16. ${ }^{*}$ C. dubia Richard, 1895 & 6,7 \\
\hline 17. *Simocephalus vetulus (O. F. Müller, 1776) & 6,7 \\
\hline 18. S. serrulatus (Koch, 1841) & $6,7,9$ \\
\hline 19. Simocephalus sp. King, 1853 & 6,7 \\
\hline 20. ${ }^{*}$ S. elizabethae (King, 1853 ) & 6,7 \\
\hline 21. S. mixtus G. O. Sars, 1903 & $\star$ \\
\hline 22. Moinodaphnia macleayi (King, 1853) & $1,2,3,4,6,7$ \\
\hline 23. * Moina micrura Kurz, 1874 & 6,7 \\
\hline 24. M. affinis Birge, 1893 & $4,2,6,7$ \\
\hline 25. M. reticulata (Daday, 1905) & 6,7 \\
\hline 26. M. juanae Brehm, 1948 & 1,6 \\
\hline 27. M. dumonti Kotov, Elías-Gutierrez \& Granados-Ramírez, 2005 & 12 \\
\hline \multicolumn{2}{|l|}{ BOSMINIDAE Baird, 1845} \\
\hline 28. Bosmina (Bosmina) longirostris (O. F. Müller, 1785) & $6,7^{\wedge}$ \\
\hline 29. B. (Liederobosmina) hagmanni (Stingelin, 1904) s.l. & $13^{\mathbf{4}}$ \\
\hline 30. B. (Liederobosmina) tubicen Brehm, 1953 & $6,7^{\star}$ \\
\hline \multicolumn{2}{|l|}{ ILYOCRIPTIDAE Smirnov, 1992} \\
\hline 31. Ilyocryptus spinifer Herrick, 1884 & $1,4,5,6,7,9,14$ \\
\hline
\end{tabular}




\section{TABLE I}

(Continued)

\begin{tabular}{|c|c|}
\hline Taxon & Source \\
\hline \multicolumn{2}{|l|}{ MACROTHRICIDAE Norman \& Brady, 1867} \\
\hline 32. Grimaldina brazzai Richard, 1892 & $5,6,7,10,14$ \\
\hline 33. * Macrothrix rosea (Liévin, 1848 ) & 6,7 \\
\hline 34. ${ }^{*}$ M. triserialis Brady, 1886 & $4,6,9,10$ \\
\hline 35. M. goeldi Richard, 1897 & $1,6,7$ \\
\hline 36. M. elegans G. O. Sars, 1901 & $1,6,7$ \\
\hline 37. M. spinosa King, 1953 & 10,14 \\
\hline 38. *M. pseudospinosa Smirnov, 1992 & 13 \\
\hline \multicolumn{2}{|l|}{ CHYDORIDAE Stebbing, 1902} \\
\hline 39. Chydorus ciliatus Poggenpol, 1874 & 9 \\
\hline 40. C. eurynotus G. O. Sars, 1901 & $4,6,7$ \\
\hline 41. C. nitidulus (G. O. Sars, 1901) & 13 \\
\hline 42. C. pubescens G. O. Sars, 1901 & $6,7,14$ \\
\hline 43. Ephemerophorus barroisi (Richard, 1894) & 6,7 \\
\hline 44. E. hybridus (Daday, 1905) & $1,6,7,9$ \\
\hline 45. *Alonella excisa (S. Fischer, 1854) & 7 \\
\hline 46. Disparalona dadayi Birge, 1910 & 6,7 \\
\hline 47. ${ }^{*}$ Dunhevedia crassa King, 1853 & 6,7 \\
\hline 48. D. setigera (Birge, 1879$)$ & 夫 \\
\hline 49. D. serrata Daday, 1898 & $4,6,9$ \\
\hline 50. D. odontoplax G. O. Sars, 1901 & $3,4,6,9$ \\
\hline 51. Pseudochydorus globosus (Baird, 1850) & 6,7 \\
\hline 52. *Alona pulchella King, 1853 & 6,7 \\
\hline 53. ${ }^{*}$ A. rustica Scott, 1895 & 6,7 \\
\hline 54. A. monacantha G. O. Sars, 1901 & $6,10,14^{\mathrm{x}}$ \\
\hline 55. A. verrucosa G. O. Sars, 1901 & $6,7,9$ \\
\hline 56. A. circumfimbriata Megard, 1967 & 9 \\
\hline 57. Leberis davidi (Richard, 1895) & $1,6,7$ \\
\hline 58. ${ }^{*}$ Camptocercus rectirostris Schoedler, 1862 & 4,7 \\
\hline 59. ${ }^{*}$ C. australis G. O. Sars, 1896 & 6,7 \\
\hline 60. ${ }^{*}$ Oxyurella tenuicaudis (G. O. Sars, 1862$)$ & 6,7 \\
\hline 61. ${ }^{*}$ Notoalona globulosa (Daday, 1898$)$ & $6,10,14$ \\
\hline 62. ${ }^{*}$ Euryalona orientalis (Daday, 1898 ) & 6,7 \\
\hline 63. E. occidentalis G. O. Sars, 1901 & $4,6,7$ \\
\hline 64. Kurzia polyspina $\mathrm{Hudec}, 2000$ & 7 \\
\hline 65. ${ }^{*}$ Leydigia acanthocercoides (Fischer, 1854) & $4,6,7$ \\
\hline $66 .{ }^{*}$ L. leydigi $($ Schoedler, 1863$)$ & 6,7 \\
\hline 67. L. louisi Jenkin, 1934 & $\star$ \\
\hline 68. L. cf. striata Birabén, 1939 & $\star$ \\
\hline 69. Leydigiopsis ornata Daday, 1905 & 6,7 \\
\hline 70. Pseudevadne tergestina Claus, 1877 & $14^{\star}$ \\
\hline
\end{tabular}


American representatives of the genus belong to the former species. In the original description of D. birgei, 16 localities from Cuba are included, which material was collected between 1964 and 1966. Nevertheless, it should be noted that recently Korovchinsky $(2002,2005)$, after the description of two related taxa from the United States, concluded that most probably $D$. birgei represents a complex of cryptic species. The forms from Cuba should be re-analysed considering this view. As an example, Elías-Gutiérrez et al. (2008b) found (based on molecular and morphological evidence) that $D$. birgei is restricted to the northern portion of the North American continent.

Latonopsis australis G. O. Sars, 1888 was recognized as a group of species by Korovchinsky (1992). It has been recorded mainly in the tropics, but Birge (1892) described L. occidentalis from temperate North America. Actually, the identity of American tropical Latonopsis has not been properly defined. In the case of Latonopsis fasciculata Daday, 1905, it is considered a junior synonym of Sarsilatona serricauda (Sars, 1901) (cf. Korovchinsky, 1992), a rare species found on the Yucatan peninsula as well (Korovchinsky \& Elías-Gutiérrez, 2000).

Daphniidae. - The genus Daphnia is almost restricted to northern latitudes. In the case of Cuba, four species have been recorded. D. ambigua, described from the U.K. by Scourfield (1947), certainly could represent a group of species. Recently, Hebert et al. (2003) found four phylo-groups of D. ambigua in North America with a $4 \%$ divergence in mitochondrial DNA. Most probably the specimens from Cuba should be considered as related with the East group, defined by Hebert et al. (2003), distributed from New York to Florida.

Another possible complex of species is found in D. laevis, distributed over North and South America, as well as in Africa (Benzie, 2005). Taylor et al. (1998) concluded to the existence of five groups in North America of this Daphnia, one of these, the "Atlantic", that dwells down to Mexico and which was designated by these authors as D. laevis gessneri, and could be the one closer to the Cuban material.

The occurrence of D. parvula Fordyce, 1901 and D. pulicaria Forbes, 1893 (members of the D. pulex Leydig, 1860 group) is not surprising, because these seem to be among the most widespread species in the Americas (Benzie, 2005).

The genus Ceriodaphnia is one of the most confusing among Daphniidae. Some species, such as the $C$. cornuta G. O. Sars, 1885 s.l., demonstrate wide morphological diversity and broad distribution. Any effort to clarify this complex will demand molecular and morphological analysis of topotypic material (ElíasGutiérrez et al., 2008b). In this regard, we note that C. cornuta, originally described from Australia (Sars, 1885), has been also recorded from elsewhere, i.e., from the type locality (Australia) to America and Africa (Berner, 1985). A similar case is C. rigaudi Richard, 1894 described from Tonkin, Viet Nam (Richard, 1894b), 
but recorded from the tropics to temperate regions. The latter represents a species complex in Mexico (Elías-Gutiérrez et al., 2008b).

In accordance with Orlova-Bienkowskaja (2001), Simocephalus vetulus (O. F. Müller, 1776) is a species restricted to Europe and North Africa. In the Americas, it has usually been confused with S. mixtus G. O. Sars, 1903. The latter species has been recorded from Jamaica by Orlova-Bienkowskaja (2001), so its occurrence in Cuba is expected. A subspecies, S. vetulus elizabethae (King, 1853), recorded by Orghidan \& Negrea (1970), and actually considered to be distinguished at species level by Orlova-Bienkowskaja (2001), is restricted to Australia and Asia. So, its occurrence in Cuba would be strange, unless an introduction has occurred. The aforementioned taxon could also be confused with $S$. mixtus.

A moinid, Moina juanae Brehm, 1948, described from Laguna de Ariguanabo (Brehm, 1948) was synonymized by Goulden (1968) with Moinodaphnia macleayi (King, 1853). Recently, the supposedly lost material of Brehm was discovered in Austria, but not all samples have yet been ordered (A. A. Kotov, in litt.). We believe that both species could be found on Cuba. Goulden (1968) synonymized this species based only on some poor quality drawings. We consider that M. juanae could be a valid species, but the type locality has been dried up due to agricultural use. From the small pools remaining it has not been possible to find any moinid (C. Varela, pers. obs.).

In addition, all records of M. micrura Kurz, 1874 should be carefully analysed. This species was described from Austria (Kurz, 1874) and then recorded from many regions of the world. Elías-Gutiérrez et al. (2008b) found profound divergence in the COI mitochondrial gene among several "micrura"-like populations from Mexico, so this name should be used with care.

Kotov et al. (2005) recently described Moina dumonti from the Yucatan Peninsula, and populations from Playa de Guanabo, Cuba seem to be conspecific.

Bosminidae. - Paggi (1979) demonstrated that Bosmina (Eubosmina) hagmanni could easily be confused with B. (E.) huaronensis Delachaux, 1918, a South American species. In fact, Deevey \& Deevey (1971) identified specimens from Arizona resembling $B$. huaronensis as $B$. hagmanni. We cannot definitively confirm the identification of the specimens from Cuba, because B. hagmanni was originally described from South America as well (Stingelin, 1904), but it has been recorded in the U.S.A. (De Melo \& Hebert, 1994; Taylor et al., 2002). V. Kořínek (in litt.) suggested to consider $B$. hagmanni s.l., from the point of view that it would represent a group of sibling species.

Ilyocryptidae. - So far, the only ilyocryptid reported from Cuba is Ilyocryptus spinifer Herrick, 1884. In their re-description of this species, Kotov \& Williams (2000) examined material from Lake La Luisa, near La Habana. Brehm (1948) 
recorded I. halyi Brady, 1886, by now considered a junior synonym of I. spinifer (cf. Kotov \& Štifter, 2006).

Macrothricidae. - "Macrothrix triserialis" recorded by Orghidan \& Negrea (1973) and Collado et al. (1984) is a complex of cryptic species. Dumont et al. (2002) redescribed M. triserialis Brady, 1886, originally described from Sri Lanka (Brady, 1886), and found its distribution restricted to the Old World. American representatives of this group are Macrothrix agsensis Dumont, Silva-Briano \& Babu, 2002 and Macrothrix smirnovi Ciros-Pérez \& Elías-Gutiérrez, 1997, both described from central Mexico, and not recorded from the tropical lowlands. Later, Kotov et al. (2004) found that the populations from Cuba, recorded by Orghidan \& Negrea (1973) belong to M. elegans G. O. Sars, 1901. In their review, Lalana et al. (2005) kept the record by Korrínek (1984) of M. superaculeata (Smirnov, 1982), though considered a junior synonym of M. elegans G. O. Sars, 1901 by Kotov et al. (2004).

M. spinosa King, 1853 has been recorded from central-southern Mexico and Central America (Van de Velde et al., 1978; Suárez-Morales \& Elías-Gutiérrez, 1992; Silva-Briano, 1998; Garfias-Espejo \& Elías-Gutiérrez, 2004), but it has been mentioned as a species that needs to be revised, in view of its apparently broad distribution across the world (Garfias-Espejo \& Elías-Gutiérrez, 2004). Smirnov (1992) considered that the M. spinosa record from the island by Korrínek (1984) could be M. flabelligera Smirnov, 1992. We consider this assumption not at fully correct, since the type locality for the latter is Australia (Smirnov, 1992). M. goeldi Richard, 1897, recorded by Collado et al. (1984), is a member of the M. spinosagroup (A. A. Kotov, pers. comm.). It was originally described from Chile by Richard (1897) and could be valid. M. pseudospinosa was described by Smirnov (1992) from Africa, and it was recorded from Cuba by V. Kořínek (in litt.), but its actual presence should be carefully analysed, based in more material.

Chydoridae. - Ephemeroporus barroisi (Richard, 1894), regarded as a group of species distributed across the world, was originally described from material collected in Syria (Richard, 1894a). Morphologically similar specimens have been recorded from Central America (Smirnov, 1996) and Mexico (Elías-Gutiérrez et al., 2001). Chydorus ciliatus Poggenpol, 1874 was considered incertae sedis by Smirnov (1996), and it is yet to be clarified if it is valid. Frey (1982) and Collado et al. (1984) recorded Kurzia latissima (Kurz, 1875) from Cuba, but later Hudec (2000) re-assigned the material to K. polyspina Hudec, 2000, described from the Mexican Pacific coast, and apparently found at several Cuban sites.

Pseudochydorus globosus (Baird, 1893) is another species that could represent a complex of congeners. It has been recorded from elsewhere, but there are some subtle differences in the American material with respect to that from the Old World (Elías-Gutiérrez et al., 2008b). 
Richard (1895) described Leberis davidi from Haiti, a taxon related with $L$. diaphanus (King, 1853) from Australia (King, 1853). Almost certainly, the populations found in Cuba belong to L. davidi. The only other American representative of this species is Leberis chihuahuensis Elías-Gutiérrez \& Valdez-Moreno, 2008 recently described from Mexico by Elías-Gutiérrez \& Valdez-Moreno (2008).

The presence of Alonella excisa (Fischer, 1854) could also be doubtful. Although it is regarded a possible cosmopolitan (Elías-Gutiérrez et al., 2008a), it has not been recorded from the tropics. The systematics of Dunhevedia are not clear. Orghidan \& Negrea (1970) recorded Dunhevedia crassa King, 1853 but ElíasGutiérrez et al. (2008a) stated that American records of this Australian species could be related to D. setigera (Birge, 1879).

Alona rustica Scott, 1895 is another doubtful record, because it is regarded as an acidic water species, mostly distributed to the Holarctic region, although some Neotropical records exist (Alonso, 1996). The tropical A. pulchella King, 1853 has been recorded from the Old World and Australia. This, and the record by Infante (1980) from Venezuela, should be revised, as well as both records of Camptocercus Baird, 1843.

Oxyurella tenuicaudis (G. O. Sars, 1862) is a Holarctic taxon. Neotropical species of the genus are $O$. longicaudis (Birge, 1910) and $O$. ciliata Bergamin, 1939, both recently recorded on the continent by Elías-Gutiérrez et al. (2006), so O. tenuicaudis from Cuba possibly is a misidentification.

Rajapaksa \& Fernando (1987) established the genus Notoalona for the Alonalike chydorids with headpores represented by two bean-like thickenings. Two species have been recorded near Cuba, N. freyi Rajapaksa \& Fernando, 1987 described from Florida, and $N$. cf. globulosa Daday, 1898, found near the Mexican Gulf coast by Elías-Gutiérrez et al. (2001). The latter authors concluded that $N$. cf. globulosa could in reality be related to "Alonella" sculpta G. O. Sars, 1901 described from Ipiranga (Brazil) by Sars (1901), a taxon not yet clarified and described in detail.

According to Kotov (2003), Leydigia leydigi (Schoedler, 1863) is restricted to the Palearctic. Cuban material, if related with L. leydigi, could be L. louisi Jenkin, 1934 described from Africa and then found in the Americas from Mexico to Argentina. The other Leydigia, L. acanthocercoides (Fischer, 1854) is restricted to the Old World, but it has been commonly confused with $L$. cf. striata Biraben, 1939 found on the Gulf Plateau of Mexico and the Yucatan Peninsula (Kotov et al., 2003). Keeping in mind the close geographical position of these regions to Cuba, and the affinity found in other species from Yucatan (i.e., Moina dumonti Kotov, Elías-Gutiérrez \& Granados-Ramírez, 2005), it is more possible to find $L$. cf. ciliata or L. striata than L. acanthocercoides on the island. 
General remarks

From the total number of species (70), about $32 \%$ require confirmation or are doubtful records. Actually, a new survey through the entire island is needed to actualize this list, and most probably many new records could be found. It should be pointed out that cladoceran systematics significantly improved during the last decade, when more than 50 new species have been described. Additionally, two new families, one suborder, and an extinct order have been proposed (Dumont \& Silva-Briano, 1998; Santos-Flores \& Dodson, 2003; Van Damme et al., 2007; Kotov, 2007).

From a biogeographical point of view, we can say in general terms that the fauna of Cuba is closely related to that of southern Mexico, and both regions have a close similarity to South America. Records such as Pseudosida ramosa (Daday, 1904), four species of Chydorus Leach, 1816, Ephemoroporus hybridus (Daday, 1905), Euryalona occidentalis (Daday, 1898), Dunhevedia odontoplax G. O. Sars, 1901, Alona monacantha G. O. Sars, 1901, Alona verrucosa G. O. Sars, 1901, and Leydigiopsis ornata Daday, 1905 have a clear South American affinity that extends towards Central America and the southern lowlands of Mexico. In this case, the distribution of these and related species seems to be similar to that of cyclopine copepods discussed by Suárez-Morales et al. (2004). The Proto-Antilles-Central America complex played a key role in the actual distribution of the species found on the continental part and the Greater Antilles, among which Cuba is the most diverse representative (Suárez-Morales et al., 2004).

\section{ACKNOWLEDGEMENTS}

V. Kořínek gave us access to his list of Cuban cladocerans and confirmed the presence of some species. A. Kotov kindly corrected the original manuscript and gave us valuable information.

\section{REFERENCES}

Alonso, M., 1984. Crustáceos y rotíferos de la laguna del Tesoro (Cuba). Limnetica, 1: 70-77.

— - 1996. Crustacea, Branchiopoda. Fauna Iberica, 7: 1-486. (Museo Nacional de Ciencias Naturales, Consejo Superior de Investigaciones Científicas, Madrid).

BenzIE, J. A. H., 2005. Cladocera: the genus Daphnia (including Daphniosis): 1-376. (Kenobi Productions \& Backhuys Publishers, Ghent, Leyden).

BERnER, D. B., 1985. Morphological differentiaton among species in the Ceriodaphnia cornuta complex (Crustacea, Cladocera). Verh. internat. Verein. Limnol., 22: 3099-3103.

Biochino, G. I., 1976. Caracterización de la fauna de la vegetación de los embalses de Cuba. Academia de Ciencias de Cuba, (Forestal) 33: 1-6.

BIRGE, E. A., 1892. List of Crustacea Cladocera from Madison, Wisconsin. Trans. Wisconsin Acad. Sci. Arts \& Lett., 8: 379-398. 
BRADY, G. S., 1886. Notes on Entomostraca collected by Mr. Haly in Ceylon. Linn. Journ. Zool., 19: 293-317.

Brehm, V., 1948. Datos para la fauna de agua dulce de Cuba. Publ. Inst. Biol. aplicada, 5: 95-112.

Collado C., C. H. Fernando \& D. Sephton, 1984. The freshwater zooplankton of Central America and the Caribbean. Hydrobiologia, 113: 105-119.

Deevey, E. S., JR. \& G. B. DeEvey, 1971. The American species of Eubosmina Crustacea Cladocera. Limnol. Oceanogr., 16: 201-218.

De Melo, R. \& P. D. N. HeberT, 1994. A taxonomic reevaluation of North American Bosminidae. Canadian Journal of Zoology, 72: 1808-1825.

Dumont, H. J. \& M. Silva-BRIANO, 1998. A reclassification of the anomopod families Macrothricidae and Chydoridae, with the creation of a new suborder, the Radopoda (Crustacea: Branchiopoda). Hydrobiologia, 384: 119-149.

Dumont, H. J., M. Silva-Briano \& K. K. S. BABU, 2002. A re-evaluation of the Macrothrix rosea-triserialis group, with the description of two new species (Crustacea Anomopoda: Macrothricidae). Hydrobiologia, 467: 1-44.

Elías-Gutiérrez, M., A. A. Kotov \& T. Garfias-Espejo, 2006. Cladocera (Crustacea: Ctenopoda, Anomopoda) from southern Mexico, Belize and northern Guatemala, with some biogeographical notes. Zootaxa, 1119: 1-27.

Elías-Gutiérrez, M., F. Martínez-Jerónimo, N. V. IVAnova, M. Valdez-Moreno \& P. D. N. HEBERT, 2008 (cf. b). DNA barcodes for Cladocera and Copepoda from Mexico and Guatemala, highlights and new discoveries. Zootaxa, 1839: 1-42.

Elías-Gutiérrez, M., N. N. Smirnov, E. SuÁrez-Morales \& N. Dimas-Flores, 2001. New and little known cladocerans (Crustacea: Anomopoda) from southeastern Mexico. Hydrobiologia, 442: 41-54.

Elías-Gutiérrez, M., E. SuÁrez-Morales, M. Gutiérrez-Aguirre, M. Silva-Briano, J. G. Granados-Ramírez \& T. Garfias-Espejo, 2008 (cf. a). Guía ilustrada de los microcrustáceos (Cladocera y Copepoda) de las aguas continentales de México: 1-367. (Universidad Nacional Autónoma de México, Mexico).

Elías-Gutiérrez, M. \& M. VAldeZ-Moreno, 2008. A new cryptic species of Leberis Smirnov, 1989 (Crustacea, Cladocera, Chydoridae) from the Mexican semi-desert region, highlighted by DNA barcoding. Hidrobiológica, 18: 63-74.

FREY, D. G., 1982. Questions concerning cosmopolitanism in Cladocera. Arch. Hydrobiol., 93: 484-502.

Garfias-Espejo, T. \& M. ElíAs-Gutiérrez, 2004. Taxonomy and distribution of Macrothricidae (Crustacea: Anomopoda) in southeastern Mexico, northern Guatemala and Belize. An. Inst. Biol., 74: 105-134.

Goulden, C. E., 1968. The systematics and evolution of the Moinidae. Trans. American microsc. Soc., 58: 1-101.

Hebert, P. D. N., J. D. S. Witt \& S. J. Adamowicz, 2003. Phylogeographical patterning in Daphnia ambigua: regional divergence and intercontinental cohesion. Limnol. Oceanogr., 48: 261-268.

HudeC, I., 2000. Subgeneric differentiation within Kurzia (Crustacea: Anomopoda: Chydoridae) and a new species from Central America. Hydrobiologia, 421: 165-178.

InfAnte, A., 1980. Los cladóceros del lago de Valencia. Acta Científica Venezolana, 31: 593-603.

KING, R. L., 1853. On Australian Entomostraca. Proc. Royal Soc. Tasmania, 21: 253-263.

KoŘíneK, V., 1981. Diaphanosoma birgei n. sp. (Crustacea, Cladocera). A new species from America and its widely distributed subspecies Diaphanosoma birgei ssp. lacustris n. ssp. Canadian Journ Zool., 59: 1115-1121.

— - 1984. Cladocera. Hydrobiological survey of the Lake Bangweulu Luapula River basin. Cercle Hydrobiol. Bruxelles, 13(2): 1-117. 
Korovchinsky, N. M., 1992. Sididae and Holopediidae: 1-82. (Guides to the Identification of the Microinvertebrates of the Continental Waters of the World, 3; SPB Academic Publishing, Amsterdam).

— - 2002. Description of two new species of Diaphanosoma Fischer, 1850 (Crustacea, Branchiopoda, Sididae) from the United States and Canada and species richness of the genus in North America. Hydrobiologia, 489: 45-54.

— - 2005. Two new species of Diaphanosoma Fischer, 1850 (Crustacea: Branchiopoda: Cladocera) from the United States. Int. Review Hydrobiol., 90: 201-208.

Korovchinsky, N. M. \& M. ElíAs-GutiÉRrez, 2000. First record of Sarsilatona serricauda (Sars, 1901) (Crustacea: Branchiopoda: Sididae) from Mexico, with redescription of its male. Arthropoda Selecta, 9: 5-11.

Kotov, A. A., 2003. Separation of Leydigia louisi Jenkin, 1934 from L. leydigi (Schoedler, 1863) (Chydoridae, Anomopoda, Cladocera). Hydrobiologia, 490: 147-168.

— - 2007. Jurassic Cladocera (Crustacea, Branchiopoda) with a description of an extinct Mesozoic order. Journ. nat. Hist., London, 41: 13-37.

Kotov, A. A., M. Elías-Gutiérrez \& J. G. Granados-Ramírez, 2005. Moina dumonti sp. nov. (Cladocera, Anomopoda, Moinidae) from southern Mexico and Cuba, with comments on moinid limbs. Crustaceana, 78: 41-57.

Kotov, A. A., T. Garfias-Espejo \& M. Elías-Gutiérrez, 2004. Separation of two Neotropical species: Macrothrix superaculeata (Smirnov, 1982) versus M. elegans Sars, 1901 (Macrothricidae, Anomopoda, Cladocera). Hydrobiologia, 517: 61-88.

Kotov, A. A., H. Ishida \& D. J. TAYLOR, 2009. Revision of the genus Bosmina Baird, 1845 (Cladocera: Bosminidae), based on evidence from male morphological characters and molecular phylogenies. Zool. Journ. Linn. Soc. London, 156: 1-51.

Kotov, A. A. \& P. ŠTIFTER, 2006. Cladocera: family Ilyocryptidae (Branchiopoda: Cladocera: Anomopoda): 1-172. (Guides to the Identification of the Micro-invertebrates of the Continental waters of the world, 22: Kenobi Productions \& Backhuys Publishers, Ghent, Leyden).

Kotov, A. A., K. VAn Damme \& M. Elías-Gutiérrez, 2003. Differentiation between African Leydigia ciliata Gauthier, 1939 and Neotropical L. cf. striata Biraben, 1939 (Chydoridae, Anomopoda, Cladocera). Hydrobiologia, 505: 179-197.

Kotov, A. A. \& J. L. Williams, 2000. Ilyocryptus spinifer Herrick, 1882 (Anomopoda, Branchiopoda): a redescription based on North American material and designation of a neotype from Minnesota. Hydrobiologia, 428: 67-84.

KURZ, W., 1874. Dodekas neuer Cladoceren nebst einer kurzen Übersicht der Cladocerenfauna Böhmens. Sitzber. Acad. Wiss. Wien, (Math. Naturw.) 70: 7-88.

Lalana, R., M. ORTiz \& C. Varela, 2005. Primera adición a la lista de los crustáceos no decápodos de Cuba. Revista de Biología, 19: 50-56.

Orghidan, T. \& S. NegreA, 1970. Quelques Cladocères des eaux souterraines et épigées de Cuba. Trav. Inst. Spéol. Emile Racovitza, 9: 113-120.

— \& \& —, 1973. Cladocères des eaux souterraines et épigées de Cuba (II): 105-115. (Résultats des Expéditions Biospéologiques Cubano-Roumaines à Cuba, Bucharest).

ORLOVA-BIENKOWSKAJA, M. J., 2001. Cladocera: Anomopoda: Daphniidae: genus Simocephalus: 1-130. (Backhuys Publishers, Leyden).

PAGGI, J. C., 1979. Revisión de las especies argentinas del género Bosmina Baird, agrupadas en el subgénero Neobosmina Lieder (Crustacea: Cladocera). Acta zool. Lilloana, 35: 137-162.

RAJAPAKSA, R. \& C. H. FERnANDO, 1987. Redescription and assigment of Alona globulosa Daday, 1898 to a new genus Notoalona and description of Notoalona freyi $\mathrm{n}$. sp. Hydrobiologia, 144: 131-153.

Richard, J., 1894a. Cladocères recueillis par le Dr. Théod. Barrois en Palestine, en Syrie et en Égypte. Rev. biol. Nord Français, 6 (9): 360-378. 
— - 1894b. Sur quelques animaux intérieurs des eaux douces du Tonkin (Protozoaires, Rotifères, Entomostraces). Mém. Soc. zool. France, 7: 237-243.

_ —, 1895. Sur quelques Entomostracés d'eau douce d'Haïti. Mém. Soc. zool. France, 8: 189-199.

— —, 1897. Entomostracés de l'Amérique du Sud, recueillis par MM. U. Deiters, H. von Inering,

G. W. Müller et C. O. Poppe. Mém. Soc. zool. France, 10: 263-301.

Santos-Flores, C. J. \& S. I. Dodson, 2003. Dumontia oregonensis n. fam., n. gen., n. sp., a cladoceran representing a new family of 'water-fleas' (Crustacea, Anomopoda) from USA, with notes on the classification of the order Anomopoda. Hydrobiologia, 500: 145-155.

SARS, G. O., 1885. On some Australian Cladocera, raised from dried mud. Forhand. VidenskabsSelskabet Christiania, 8: 1-46.

— - 1901. Contributions to the knowledge of the fresh-water Entomostraca of South America, as shown by artificial hatching from the dried material. Arch. Mathemat. Naturv., 23: 1-102.

SCOURFIELD, D. J., 1947. A short-spined Daphnia presumably belonging the longispina group D. ambigua sp. n. Journ. Queckett microsc. Club, 4: 127-131.

Silva-Briano, M., 1998. A revision of the macrothricid-like anomopods: 1-388. (Ph.D. Thesis, Universiteit Ghent, Ghent).

Smirnov, N. N., 1992. The Macrothricidae of the world: 1-143. (Guides to the Identification of the Microinvertebrates of the Continental Waters of the World, SPB Academic Publishing, Amsterdam).

— —, 1996. Cladocera: The Chydorinae and Sayciinae (Chydoridae) of the World: 1-197. (Guides to the Identification of the Microinvertebrates of the Continental Waters of the World, SPB Academic Publishing, Amsterdam).

Stingelin, T., 1904. Entomostracen, gesammelt von Dr. G. Hagmann in Mündungsgebiet des Amazonas. Zool. Jahrb., 20: 575-590.

StrašKrabA, M., 1969. Lista de los crustáceos dulceacuícolas de Cuba y sus relaciones zoogeográficas. Cuba, Academia de Ciencias, (Biol.) 8: 1-37.

StrašKraba, M., M. Legner, J. Foot, J. Holcik, K. Komartova Legnerova, K. HolciKova \& M. PÉREZ EIRIZ, 1969. Primera contribución al conocimiento limnológico de las aguas y embalses de Cuba. Cuba, Academia de Ciencias, (Biol.) 4: 1-44.

SuÁreZ-Morales, E. \& M. ElíAs-GutiérreZ, 1992. Cladóceros (Crustacea: Branchiopoda) de la reserva de la biósfera de Sian Ka'an Quintana Roo y zonas adyacentes. In: D. NAVARRO \& E. SUÁreZ-Morales (eds.), Diversidad biológica en la reserva de la biósfera de Sian Ka'an Quintana Roo, México, 2: 145-160. (CIQRO/SEDESOL, Mexico).

SuÁReZ-Morales, E., J. W. ReID, F. Fiers \& T. M. ILIFFE, 2004. Historical biogeography and distribution of the freshwater cyclopine copepods (Copepoda, Cyclopoida, Cyclopinae) of the Yucatan peninsula, Mexico. Journal of Biogeography, 31: 1051-1063.

TAYlor, D. J., T. L. Finston \& P. D. N. Hebert, 1998. Biogeography of a widespread freshwater crustacean: pseudocongruence and cryptic endemism in the North American Daphnia laevis complex. Evolution, 52: 1648-1670.

TAYlor, D. J., C. R. Ishikane \& R. A. HANEY, 2002. The systematics of Holarctic bosminids and a revision that reconciles molecular and morphological evolution. Limnol. Oceanogr., 47: 1486-1495.

Van Damme, K., R. J. Shiel \& H. J. Dumont, 2007. Notothrix halsei gen. n., sp. n., representative of a new family of freshwater cladocerans (Branchiopoda, Anomopoda) from SW Australia, with a discussion of ancestral traits and a preliminary molecular phylogeny of the order. Zool. Scripta, 36: 465-487.

VAn DE Velde, I., H. J. Dumont \& P. GRootaert, 1978. Report on a collection of Cladocera from Mexico and Guatemala. Arch. Hydrobiol., 83: 391-404.

First received 4 April 2008.

Final version accepted 13 October 2008. 